\title{
Business Diplomacy from an IR Perspective
}

\author{
Niels van Willigen \\ Leiden University, Netherlands \\ willigen@fsw.leidenuniv.nl
}

\section{Introduction}

In spite of globalization and the concomitant increasing importance of nonstate actors, including Transnational Corporations (TNCs), the role of business in world affairs still is a relatively small topic within the discipline of international relations (IR) and in the sub-fields of foreign policy analysis (FPA) and International Political Economy (IPE). A quick scan of several text books on IR, show that coverage of TNCs as actors in world politics is still limited compared to other actors, including states, International Governmental Organizations (IGOs) and Non-Governmental Organizations (NGOs). ${ }^{1}$ Moreover, there is hardly any attempt to incorporate businesses in the theoretical approaches. This seems odd, given the widespread view that TNCs have become political actors that influence government policies. But instead of focusing on TNCs and other businesses as actors, most attention seems to go to the more abstract forces of the free market that are pushing globalization. ${ }^{2}$

The lack of attention for businesses as political actors also means that the idea of businesses as diplomatic actors has not really been taken up yet; in spite of an emerging body of literature focusing on business diplomacy. Business diplomacy, also called corporate diplomacy or corporate business diplomacy in the literature, refers to activities undertaken by commercial actors (and is thus not limited to TNCs) that resemble diplomacy in the traditional meaning of the term. In a special issue of The Hague Journal of Diplomacy it has been defined as "an approach to geopolitical and non-commercial risk

1 Baylis, J., S. Smith, and P. Owens, eds. The Globalization of World Politics (Oxford: Oxford University Press, 2018); Heywood, A. Global Politics, $2^{\text {nd }}$ ed. (Basingstoke: Palgrave Macmillan, 2014); Grieco, J., G.J. Ikenberry, and M. Mastanduno. Introduction to International Relations. Perspectives. Connections, and Enduring Questions (London: Red Globe Press, 2019).

2 Mikler, J. The Political Power of Global Corporations (Cambridge: Polity Press, 2018), 1. 
management that is based on the practices and mindset of diplomats." ${ }^{3}$ In other words, it is what businesses do to "deal with obstacles" to their commercial operations. ${ }^{4}$ The purpose of business diplomacy is "to maintain legitimacy, and a license to operate." ${ }^{5}$ The definitions make clear that business diplomacy is very much focused on the interests of the businesses. That makes it different from commercial diplomacy and economic diplomacy; two activities that take into account the interests of both businesses and governments.

As a topic, business diplomacy surely has the potential to enrich the discipline of IR and its sub-disciplines. But how exactly should we consider business as a diplomatic actor in international relations? Building on the business diplomacy literature I argue that in order to promote business diplomacy as a concept enriching IR and enabling theorizing, we need a richer understanding of the concept. I offer a critical assessment of business diplomacy as an activity resembling state diplomacy. I argue that the definitions mentioned above are a good starting point, but that a richer conceptualization, which takes more into account the variety of businesses and the diverse nature of diplomacy, is needed. History can teach us about this variety and it can also provide us with insights into the political, economic and social context of business diplomacy as I explain in the last section. In the remainder of this essay I present several elements that I propose should be part of such a richer conceptualization.

\section{What Kind of Risks?}

As shown by the definitions above business diplomacy is primarily formulated in negative terms: it is about geopolitical risk management and taking away obstacles. The analysis is that the forces of globalization and the increase of geo-political tensions have made business diplomacy necessary for businesses to survive. ${ }^{6}$ However, "geopolitical and non-commercial risk" is insufficiently defined in the literature and it threatens to make business diplomacy an empty concept. In IR, the term "geo-political" is normally reserved to describe great

3 Kesteleyn, J., S. Riordan, and H.J. Ruël. “Introduction: Business Diplomacy." The Hague Journal of Diplomacy, 9 (4) (2014), 303.

4 Saner, R., Y. Lichia, and S. Mikael. "Business Diplomacy Management: A Core Competency for Global Companies." The Academy of Management Executive (1993-2005) 14 (1) (2000), 80-92, 80.

5 Ruël, H.J., and T. Wolters. "Business Diplomacy." In The SAGE Handbook of Diplomacy, eds. C. Constantinou, P. Kerr, and P. Sharp (Los Angeles: Sage, 2016).

6 Riordan, S. Business Diplomacy. Shaping the Firm's Geopolitical Risk Environment (The Hague: Netherlands Institute of International Relations Clingendael, 2014). 
power politics that emphasizes the role of geography in international relations and which is closely related to the concept of the nation state. Its direct relevance for business diplomacy, which has a transnational character, is not obvious and would need to be defined and qualified. That is different for the concept of "non-commercial risk" (which, to be fair, might be a consequence of geopolitics) that is relevant in the sense that any company is potentially vulnerable to non-commercial risk. However, non-commercial risks can mean very different things; risks related to stricter legislation (for example environmental standards or labor standards); political, economic and military sanctions; expropriation; revolutions; state collapse; and other political events. This variety needs to be taken into account, because, for example, stricter environmental standards might call for a different kind of business diplomacy than the risk of state collapse.

\section{3}

\section{What Kind of Diplomacy?}

If we take the claim seriously that business diplomacy is about business executives assuming diplomatic roles, the definition should include a variety of diplomatic approaches. After all, state diplomacy is not only about risk reduction, but also about creating opportunities. As an instrument of the state, diplomacy is primarily used to create and foster long-term bilateral and multilateral relationships. The expansion of IGOs, treaties and other institutions since 1945 illustrates that states have established long-term relationships that go beyond mere risk management. Similarly, there are cases in which businesses undertake diplomatic activities that cannot aptly be described as risk reduction. For example, the participation of businesses in the implementation of the United Nations Sustainable Development goals is a value-based policy in which participating businesses recognize that it is in their long-term business interest to contribute to these goals. This resembles the argument found in neoliberal institutionalist IR theory that states are egoistic actors and focus on self-interest, but nonetheless cooperate with each other. Cooperation is considered to be the best way to promote one's interests and is therefore compatible with the notion of state egoism. So, it is important to recognize that businesses are involved in both bilateral and multilateral diplomacy and that it does not only involve risk management. Such a perspective would also enable the application of institutionalist theories in the analysis of business diplomacy. Corporations can be seen as (commercial) institutions that could potentially be studied for example from the perspectives of strategic behavior (rational choice institutionalism), factional interests (sociological institutionalism), and/or path dependency (historical institutionalism). 
A richer understanding of the diplomat's mindset is needed as well. What is exactly meant when it is stated in the literature that business executives adopt the "practices and mindset of diplomats" and become "corporate diplomats"?7 "Mindset" seems to refer to competences or skills, whereas "practices" seem to mean activities such as "managing multiple stakeholders at home and abroad." First, it is debatable whether diplomatic skills are really that different from business skills. These skills traditionally include negotiation skills, the power to persuade, knowing how to deal with ambiguity, crisis-management skills, decision-making skills, and leadership skills. Therefore, a business executive who masters these skills would already be quite well prepared for taking up the task of business diplomacy. Even more so, because he or she would also know how to deal with multiple stakeholders, which relates to the daily practices of the diplomat. Today, there might be a larger demand on companies to get involved in international politics than ever before, but since a long time businesses have already become used to interactions with public authorities and civil society in the domestic setting. Therefore, it is important to recognize that business diplomats do not start from zero when they get involved in business diplomacy. Of course, the business diplomat would encounter several new stakeholders, but the focus should therefore be on those stakeholders that differ from the domestic ones. The same goes for the skills: the focus should be on those skills where business executives do differ from state diplomats.

\section{5}

A Western Bias?

The notion of the "diplomat's mindset" seems to rest on the assumption that all diplomats are alike and there is such a thing as the ideal typical diplomat. This does not take into account that diplomats are part of a national political system and belong to a national political culture which may differ considerably; even among politically and culturally close states like the member states of the European Union (EU). For example, in the literature on the Europeanization of the foreign policy of EU-member states there is an explicit recognition that national differences exist, but that there is increased convergence towards a

7 Kesteleyn, J., et.al. "Introduction: Business Diplomacy," 303; Mirvis, P.H., S.T. Hurley, and A. MacArthur. "Transforming Executives into Corporate Diplomats: The Power of Global Pro Bono Service." Organizational Dynamics 43 (3) (2014), 235-45.

8 Saner et.al. "Business Diplomacy Management," 80. 
"European" foreign policy. ${ }^{9}$ Studies on the European Union's External Action Service (EEAS) also take the differences between European diplomatic practices as a starting point. ${ }^{10}$ If EU member states already differ so much when it comes to the diplomatic mindset, it can be expected that there is an even bigger difference between Western and non-Western diplomatic practices. There is increasing attention for non-Western IR in which the perspective of the Global South is taken into account. ${ }^{11}$ Many of these studies show that theories and concepts developed within Western settings do not always travel well to non-Western settings. Apart from a conceptual and theoretical sensitivity to non-Western contexts, it is also important to apply the same sensitivity to empirical studies. What are the commonalities and differences between US, African, European, Asian and South American businesses when they conduct business diplomacy? The current state of knowledge about business diplomacy rests primarily on empirical evidence of Western corporations. But studying Asian, Latin-American and African companies might lead to different conclusions and would enrich the field.

In order to get a richer conceptualization of business diplomacy it would also be necessary to open up the black box of businesses. Treating a corporation as a unitary actor would be equivalent to adopting a unitary actor perspective of the state in IR. Although this can lead to important insights, a more nuanced analysis can be made if it is recognized that business diplomacy is executed by individuals. Who are the business diplomats? Are they hired consultants or

9 Tonra, B. “Europeanization." In The SAGE Handbook of European Foreign Policy (Vol 1), eds. K.E. Jorgensen, A. Kalland Aarstad, E. Drieskens, K. Laatikainen, and B. Tonra (Los Angeles: Sage, 2015), 183-96.

10 Balfour, R. The European External Action Service and National Foreign Ministries: Convergence or Divergence? (Farnham: Ashgate, 2015); Juncos, A.E., and K. Pomorska. "Manufacturing Esprit de Corps: The Case of the European External Action Service." JCMs:Journal of Common Market Studies, 52 (2) (2014), 302-19; Morgenstern-Pomorski, J.-H. The Contested Diplomacy of the European External Action Service: Inception, Establishment and Consolidation (Abingdon, Oxon, New York, NY: Routledge, 2018).

11 Just a few recent publications: Liu, T.T.T. "Teaching $I R$ to the Global South: Some Reflections and Insights." Revista Brasileira de Política Internacional, 59 (2) (2016); Bischoff, P.H. Africa in Global International Relations: Emerging Approaches to Theory and Practice (New York: Routledge, 2016); Spies, Y.K. Global Diplomacy and International Society (Cham: Springer International Publishing, 2019); Alejandro, A. Western Dominance in International Relations? The Internationalisation of IR in Brazil and India (London: Routledge, 2019). 
business executives from within the company? What is their background? Taking the business diplomat as the unit of analysis rather than the company, it would be possible to use different kinds of FPA theories, models and frameworks that have been developed within the context of state diplomacy and that focus on the individual. It would for example be possible to execute a Leadership Trait Analysis (LTA). LTA tries to establish personal characteristics of a decision-maker and tries to connect that to her or his behavior. ${ }^{12}$ Alternatively, Operational Code Analysis (OCA) would also be interesting to apply to business diplomats. An Operational Code is a specific subset of beliefs that an individual holds about politics. For example; it contains beliefs about whether the nature of political life is primarily friendly or hostile, and beliefs about how an individual thinks that political objectives can be reached best (for example through cooperation or conflict). ${ }^{13}$ LTA, OCA and other agency orientated approaches would of course not replace studying companies as a whole, but it would add an important dimension needed to get a more valid understanding of what business diplomacy is about.

What about the "Dark Side"?

Not all business is the same and therefore not all business diplomacy might be the same. It would be worthwhile to explore whether there are different kinds of business diplomacy. A possible angle would be to study different kinds of businesses (energy, food, steel, oil etc.) and make comparative analyses. Just like the way foreign policies and diplomatic practices of states are analyzed in a comparative perspective. Another angle would be to also look at the "dark side." Hitherto, the literature has focused on businesses which try to deal with geopolitical risks from a legitimate perspective. Saner and Yiu, for example, take a normative position by highlighting that they focus on "the constructive and ethical use of business diplomacy" and do not study businesses that use business diplomacy "to pursue their illicit goals." ${ }^{14}$ However, it is impossible to get a sound understanding of business diplomacy if the illegitimate or the ethically problematic businesses are omitted. The business diplomacy of a

12 Hermann, M.G. "Explaining Foreign Policy Behavior Using the Personal Characteristics of Political Leaders." International Studies Quarterly, 24 (1) (1980), 7-46.

13 Walker, S.G., and M. Schafer. Operational Code Theory: Beliefs and Foreign Policy Decisions. (Oxford, Oxford University Press, 2010).

14 Saner, R., and L. Yiu. "Business Diplomacy Competence: A Requirement for Implementing the $O E C D$ 's Guidelines for Multinational Enterprises." The Hague Journal of Diplomacy 9 (4) (2014), 311. 
clothing firm aimed at establishing a conducive long-term relationship with a host state and which takes environmental concerns and labor standards seriously, might be very different from the business diplomacy undertaken by a private military company that does not care so much about international humanitarian law for example. Ignoring these kinds of cases would be similar to for example not studying the aggressive diplomacy of an authoritarian regime that bullies its neighboring state, which obviously would give an incomplete picture of state diplomacy.

Conclusion: What about History?

In spite of a growing body of literature, business diplomacy has not firmly entered the discipline of IR yet. Since it is a relatively new topic this is not very surprising. However, businesses have an important role to play in international politics and that merits due attention for business diplomacy. In order to become a relevant theme in IR, in would be important to increase the scope of the concept. I have sketched out several elements that could be part of a richer conceptualization. The promise of business diplomacy as a topic of study in IR is that it would give insight into an important and understudied aspect of world politics and globalization. For that to happen, historical perspectives would have to be taken into account. History provides a source base for diplomatic studies and also informs the researcher about the political, social and economic context in which business diplomacy is being conducted. Most studies of business diplomacy focus on the present, without really taking into account historical cases or historical context. Doing so would lead to a much richer understanding of business diplomacy. Although the study of business diplomacy is of recent origin, business diplomacy itself is a much older phenomenon. Historical examples in which companies had to conduct at least some form of business diplomacy include the Hanseatic League and the British or Dutch East India Companies. Historians studying these or other cases from the past could in turn benefit from the theories and models developed by IR scholars. In turn, IR scholars would do well enriching their models and theories with historical cases. 